\title{
EXPERIENCE SHOCKS OF STRATEGIC FOOD CONSUMERS IN INDONESIA DURING COVID-19 PANDEMIC
}

\author{
Fitrotul laili*, Wiwit Widyawati, Dian Islami Prasetyaningrum \\ Faculty of Agriculture, Universitas Brawijaya, Indonesia \\ "corresponding author: laili.fl@ub.ac.id
}

\begin{abstract}
COVID-19's negative externalities disrupted the supply of several commodities. Meanwhile, to combat the spread of COVID-19, various countries have implemented a lockdown policy, which impacts the economy's balance. Consumers' risks are increasing due to economic changes caused by the COVID-19 pandemic, which affects the higher level of volatility of various agricultural commodities in Indonesia, particularly strategic commodities. Thus, this research was designed to examine the experience shock of strategic food consumers during Covid-19 pandemic. The ARCH/GARCH model was used to describe the strategic food price movement pattern using a set of weekly consumer price data from March 2020 until August 2021. This study found price volatility of strategic food commodities is classified into three categories. For starters, the extreme volatility of commodities such as garlic and cayenne pepper indicates that future buyers will face more significant uncertainty and risk. Furthermore, these commodities will generate fluctuating price swings in the future, resulting in greater experience shock for consumers. Second, commodities with high price volatility, such as rice, chicken meat, eggs, shallots, and sugar, signal that these commodities will subject consumers to a huge shock due to their high price volatility. Third, minimal volatility, such as that found in meat, red chilli, and cooking oil, indicates that customers will face less uncertainty in the future.
\end{abstract}

Keywords: Experience Shock, Strategic Commodity, COVID-19 Pandemic, Consumer Price

http://dx.doi.org/10.21776/ub.agrise.2022.022.1.8

Received 1January 2022

Accepted 30 January 2022

Available online 31 January 2022

\section{INTRODUCTION}

The COVID-19 pandemic is still active and has a considerable influence on the economies of the majority of the world's countries. International financial and commodity market conditions grew by 2.9 per cent in 2019 and are expected to rise to 3.3 per cent in 2020, barring COVID-19 in China, which caused shocks in several nations. Furthermore, COVID-19's negative externalities cause supply shocks in a variety of commodities (Ezeaku et al., 2021). On the other hand, various countries are enacting lockdown policies to prevent the spread of COVID-19, which impacts economic balance (Sharif et al., 2020). The dissemination and increase in the number of cases of COVID-19 occurred in a brief period and has expanded across countries, including Indonesia. As of August 2020, there have been 17,660,523 confirmed cases, with 680,894 deaths reported in 216 countries. There have been 165,887 confirmed cases in Indonesia, with 7,169 deaths in 34 regions (Yamali \& Putri, 2020). The existence of health quarantine policies, social distancing, and large-scale social restrictions

CITATION: Laili, F., Widyawati, W., Prasetyaningrum, D. I., (2022). EXPERIENCE SHOCKS OF STRATEGIC FOOD CONSUMERS IN INDONESIA DURING COVID-19 PANDEMIC, Agricultural Socio-Economics Journal, 22(1), 
implemented by the Indonesian government has a significant impact on various sectors, including agriculture (Silalahi \& Ginting, 2020). Consumers face more significant risks due to economic changes brought on by the COVID-19 pandemic, which is impacting higher volatility levels of various agricultural commodities in Indonesia, particularly strategic commodities.

On the other hand, food price volatility will impact economic performance from both the micro and macro levels. High prices negatively impact households' fundamental food consumption decisions (Marvasti \& Lamberte, 2016). Thus, interruptions on COVID-19 in Indonesia will eventually worsen the uncertainty condition on both sides, supply and demand, which mean the worsen experience shocks that will face by the consumer during COVID-19 pandemic. Given these significant effects, an important economic policy priority is finding strategies to mitigate the negative consequences for the consumer associated with price stability in the food market. While the government, as a policymaker, can utilize this information to identify policies linked to food independence and price stability. Because Indonesia is one of the Southeast Asian countries that can endure food production deficits and food insecurity (Anindita et al., 2017). So it is critical to research the volatility of strategic food commodity prices since abrupt and severe changes in volatility will cause a financial crisis (Uddin et al., 2021) and lead to huge experience shocks for consumers due to changing affecting COVID-19 pandemic. This research aims to analyze the experience shocks of strategic food commodities consumers during COVID-19.

\section{RESEARCH METHODS}

The data used to analyze the experience shock of consumer is a weekly nominal consumer price of strategic food commodities from March 2020 to August 2021 (78 observations), data was obtained from National Strategic Food Price Information Center, Indonesia. The strategic food commodities used in this research, including rice, chicken meat, beef, egg, shallot, garlic, red chilli, cayenne pepper, cooking oil, and sugar

\section{Stationery Data Test}

The Augmented Dickey-Fuller Test were used to detect whether the prices were stationary at level or first difference that written as follow:

$$
\begin{aligned}
& \triangle Y P R_{t}=\alpha_{0}+{ }^{\gamma} P R_{t-1}+\beta_{i} \sum_{i=1}^{p} \Delta P R_{t-i+1}+\varepsilon_{t} \\
& \triangle Y P C h_{t}=\alpha_{0}+{ }^{\gamma} P C h_{t-1}+\beta_{i} \sum_{i=1}^{p} \Delta P C h_{t-i+1}+\varepsilon_{t} \\
& \triangle Y P B_{t}=\alpha_{0}+{ }^{\gamma} P B_{t-1}+\beta_{i} \sum_{i=1}^{p} \Delta P B_{t-i+1}+\varepsilon_{t}
\end{aligned}
$$

$$
\begin{aligned}
& \triangle Y P E_{t}=\alpha_{0}+{ }^{8} P E_{t-1}+\beta_{i} \sum_{i=1}^{p} \Delta P E_{t-i+1}+\varepsilon_{t} \\
& \Delta Y P S_{t}=\alpha_{0}+{ }^{\gamma} P S_{t-1}+\beta_{i} \sum_{i=1}^{p} \Delta P S_{t-i+1}+\varepsilon_{t} \\
& \triangle Y P G_{t}=\alpha_{0}+{ }^{8} P G_{t-1}+\beta_{i} \sum_{i=1}^{p} \Delta P G_{t-i+1}+\varepsilon_{t} \\
& \triangle Y P R c_{t}=\alpha_{0}+{ }^{r} P R c_{t-1}+\beta_{i} \sum_{i=1}^{p} \Delta P R c_{t-i+1}+\varepsilon_{t} \\
& \triangle Y P C_{t}=\alpha_{0}+{ }^{8} P C_{t-1}+\beta_{i} \sum_{i=1}^{p} \Delta P C_{t-i+1}+\varepsilon_{t} \\
& \triangle Y P O_{t}=\alpha_{0}+{ }^{\gamma} P O_{t-1}+\beta_{i} \sum_{i=1}^{p} \Delta P O_{t-i+1}+\varepsilon_{t} \\
& \Delta Y P S_{t}=\alpha_{0}+{ }^{\gamma} P S_{t-1}+\beta_{i} \sum_{i=1}^{p} \Delta P S_{t-i+1}+\varepsilon_{t}
\end{aligned}
$$

Where $\left(\triangle Y P R_{t}, \triangle Y P C h_{t}, \triangle Y P B_{t}, \triangle Y P E_{t}, \triangle Y P S_{t}\right.$, $\left.\triangle Y P G_{t}, \triangle Y P R c_{t}, \triangle Y P C_{t} \triangle Y P O_{t}, \triangle Y P S_{t}\right)$ are the first difference form of price series, which rice, chicken meat, beef, egg, shallot, garlic, red chilli, cayenne pepper, cooking oil, and sugar. ADF test assumes that $\mathrm{H}_{0}: \delta=0$ means no stationarity and vice versa.

\section{ARMA Order Test}

Common forms of the ARMA model $(p, q)$ are the autoregressive order $\mathrm{p}$ and the order moving average $\mathrm{q}$, which can be written in the following general equations:

$X_{t}=\mu+\sum_{i=1}^{p} \varphi_{\mathrm{i} \mathrm{X}_{\mathrm{t}-\mathrm{i}}}+\varepsilon_{\mathrm{t}}+\sum_{i=1}^{q} \theta_{\mathrm{j}} \varepsilon_{\mathrm{t}}$

\section{ARCH Effect Test}

Heteroskedasticity testing is used to demonstrate the arch effect. This test is performed to ensure that the error's variance value does not have the same variance. The assumption is that if $\operatorname{var}\left(\mu_{\mathrm{t}}\right)=\sigma^{2}$, the variance of the error is constant (homoscedasticity), hence the variance value of the error is heteroskedasticity if $\operatorname{var}\left(\mu_{\mathrm{t}}\right) \neq \sigma^{2}$. Consider numerous statistical summaries to assess the presence of heteroscedasticity in this test, one of which is the value of kurtosis (tapering); if the value is greater than three, it can be acidized as an early indication of heteroscedasticity.

\section{ARCH/GARCH Estimation}

To describe a series of data with changes in volatility, the ARCH model allows variants of the error term to change based on time. The ARMA equation above (Eq. 2) as a heteroskedastic conditional autoregressive process in which all $\varepsilon_{t}$ is shaped:

$$
\begin{aligned}
& \varepsilon_{t}=z_{t} \sigma_{t} \\
& \sigma_{t}^{2}=\omega+\sum_{i=1}^{p} \alpha_{i} \varepsilon^{2}{ }_{t-I}
\end{aligned}
$$

Therefore, GARCH model $(p, q)$ that is used in this study as follow (Piot-Lepetit, 2011):

$\sigma_{t}^{2}=\omega+\sum_{i=1}^{p} \alpha_{i} \varepsilon_{t-I}^{2}+\sum_{i=1}^{q} \beta_{j} \sigma_{t-j}^{2}$

where:

$\begin{array}{ll}\sigma_{\mathrm{t}}{ }^{2} & : \text { Conditional variance } \\ \varepsilon_{\mathrm{t}-\mathrm{I}}^{2} & : \text { Volatility in the previous period } \\ \omega & : \text { Constanta }\end{array}$


$\alpha_{\mathrm{i}} \quad$ : Coefficient of volatility in the previous period

$\beta_{j} \sigma^{2} t_{-j} \quad$ : Variance of the previous period

Summarizing of $\alpha_{i}+\beta_{j}$ showed price volatility level, if summarized of $\alpha_{i}+\beta_{j}$ closes to 1 , the tendency of price volatility is higher at the long term (Piot-Lepetit, 2011). stationary at the second difference. Furthermore, the ARCH effect test (Table 2) demonstrate that the strategic food commodities price series has an $\mathrm{ARCH}$ impact, as evidenced by the p-value of Obs* R-squared and F-statistic value less than $5 \%$. As a result, an ARCH/GARCH model is appropriate for estimating price uncertainty.

\section{RESULTS AND DISCUSSION}

According to Table 1, all strategic food commodity price series are non-stationary at the level and

\begin{tabular}{|c|c|c|c|c|c|c|c|}
\hline \multirow{2}{*}{ Commodity } & \multicolumn{2}{|c|}{ Level } & \multicolumn{2}{|c|}{ First Difference } & \multicolumn{2}{|c|}{ Second Difference } & \multirow{2}{*}{$\begin{array}{c}\text { Order of } \\
\text { Integration } \\
I(d)\end{array}$} \\
\hline & $\mathrm{ADF}$ & PP & $\mathrm{ADF}$ & PP & $\mathrm{ADF}$ & PP & \\
\hline Rice & $\begin{array}{c}-1.192692 \\
(0.9047)\end{array}$ & $\begin{array}{c}-1.437233 \\
(0.8421)\end{array}$ & $\begin{array}{l}-7.467741 \\
(0.0000)^{* *}\end{array}$ & $\begin{array}{c}-7.467574 \\
(0.0001) * *\end{array}$ & $\begin{array}{l}-9.614725 \\
(0.0000)^{* *}\end{array}$ & $\begin{array}{l}-26.84810 \\
(0.0001)^{* *}\end{array}$ & \multirow{10}{*}{ I (2) } \\
\hline Chicken Meet & $\begin{array}{l}-3.810688 \\
(0.0215)^{* *}\end{array}$ & $\begin{array}{c}-2.404367 \\
(0.3745)\end{array}$ & $\begin{array}{l}-5.202185 \\
(0.0003)^{* *}\end{array}$ & $\begin{array}{c}-5.327712 \\
(0.0002) * *\end{array}$ & $\begin{array}{l}-10.90501 \\
(0.0000) * *\end{array}$ & $\begin{array}{l}-12.59558 \\
(0.0001)^{* *}\end{array}$ & \\
\hline Beef & $\begin{array}{c}-1.576722 \\
(0.7928)\end{array}$ & $\begin{array}{c}-1.521150 \\
(0.8139)\end{array}$ & $\begin{array}{l}-4.367559 \\
(0.0044)^{* *}\end{array}$ & $\begin{array}{c}-7.594103 \\
(0.0000) * *\end{array}$ & $\begin{array}{l}-9.273311 \\
(0.0000)^{* *}\end{array}$ & $\begin{array}{l}-28.82816 \\
(0.0001) * *\end{array}$ & \\
\hline Egg & $\begin{array}{l}-3.877350 \\
(0.0179) * *\end{array}$ & $\begin{array}{c}-2.494982 \\
(0.3298)\end{array}$ & $\begin{array}{l}-3.957914 \\
(0.0144) * *\end{array}$ & $\begin{array}{c}-3.856809 \\
(0.0187) * *\end{array}$ & $\begin{array}{l}-8.645513 \\
(0.0000)^{* *}\end{array}$ & $\begin{array}{l}-9.004885 \\
(0.0001)^{* *}\end{array}$ & \\
\hline Shallot & $\begin{array}{l}-4.067438 \\
(0.0105)^{* *}\end{array}$ & $\begin{array}{c}-2.251342 \\
(0.4548)\end{array}$ & $\begin{array}{c}-2.377607 \\
(0.3881) \\
\end{array}$ & $\begin{array}{c}-2.559398 \\
(0.2998)\end{array}$ & $\begin{array}{l}-4.904953 \\
(0.0008) * *\end{array}$ & $\begin{array}{l}-7.908365 \\
(0.0001)^{* *}\end{array}$ & \\
\hline Garlic & $\begin{array}{l}-5.092524 \\
(0.0004)^{* *}\end{array}$ & $\begin{array}{c}-1.421212 \\
(0.8470)\end{array}$ & $\begin{array}{c}-2.581212 \\
(0.2900)\end{array}$ & $\begin{array}{r}-2.811315 \\
(0.1979)\end{array}$ & $\begin{array}{c}-8.899661 \\
(0.0000)^{* *}\end{array}$ & $\begin{array}{l}-8.948628 \\
(0.0000) * *\end{array}$ & \\
\hline Red Chilli & $\begin{array}{c}-1.736323 \\
(0.7253) \\
\end{array}$ & $\begin{array}{c}-1.501308 \\
(0.8209) \\
\end{array}$ & $\begin{array}{c}-3.267534 \\
(0.0796) \\
\end{array}$ & $\begin{array}{c}-3.327700 \\
(0.0696) \\
\end{array}$ & $\begin{array}{l}-8.142501 \\
(0.0000)^{* *}\end{array}$ & $\begin{array}{l}-13.09944 \\
(0.0001)^{* *} \\
\end{array}$ & \\
\hline Cayenne Pepper & $\begin{array}{c}-2.046386 \\
(0.5664) \\
\end{array}$ & $\begin{array}{c}-1.412991 \\
(0.8495) \\
\end{array}$ & $\begin{array}{c}-1.886613 \\
(0.6515) \\
\end{array}$ & $\begin{array}{r}-2.815871 \\
(0.1963) \\
\end{array}$ & $\begin{array}{l}-9.172526 \\
(0.0000) * *\end{array}$ & $\begin{array}{l}-9.023972 \\
(0.0000) * *\end{array}$ & \\
\hline Cooking Oil & $\begin{array}{c}-1.639319 \\
(0.7681) \\
\end{array}$ & $\begin{array}{c}-1.763423 \\
(0.7128) \\
\end{array}$ & $\begin{array}{c}-9.462832 \\
(0.0000)^{* *}\end{array}$ & $\begin{array}{c}-9.427891 \\
(0.0000)^{* *}\end{array}$ & $\begin{array}{l}-9.178413 \\
(0.0000)^{* *}\end{array}$ & $\begin{array}{l}-38.85722 \\
(0.0001)^{* *} \\
\end{array}$ & \\
\hline Sugar & $\begin{array}{c}-1.943727 \\
(0.6220)\end{array}$ & $\begin{array}{c}-2.630910 \\
(0.2682)\end{array}$ & $\begin{array}{l}-5.435094 \\
(0.0001)^{* *}\end{array}$ & $\begin{array}{c}-5.473929 \\
(0.0001) * *\end{array}$ & $\begin{array}{l}-6.285611 \\
(0.0000)^{* *}\end{array}$ & $\begin{array}{l}-15.92545 \\
(0.0001)^{* *}\end{array}$ & \\
\hline
\end{tabular}

Note: ADF (Augmented Dickey Fuller), PP (Philips-Peron), **showed that data is stationer in the first difference and significant at $5 \%$.

Table 2 ARCH Effect Test

\begin{tabular}{|c|c|c|c|c|}
\hline & Heteroskedastic & :ARCH & & \\
\hline \multirow{2}{*}{ Rice } & F-statistic & 7.790464 & Prob. F(1,74) & 0.0067 \\
\hline & Obs*R-squared & 7.238928 & Prob.Chi Square(1) & 0.0071 \\
\hline \multirow{3}{*}{ Chicken Meet } & F-statistic & 0.394920 & Prob. F(1,74) & 0.0053 \\
\hline & & & Prob.Chi- & \\
\hline & Obs*R-squared & 0.403440 & Square(1) & 0.0052 \\
\hline \multirow[b]{2}{*}{ Beef } & F-Statistic & 0.563073 & Prob. F $(1,74)$ & 0.0045 \\
\hline & Obs*R-Squared & 0.573924 & $\begin{array}{l}\text { Prob.Chi- } \\
\text { Square(1) }\end{array}$ & 0.0044 \\
\hline \multirow{2}{*}{ Egg } & F-statistic & 0.310708 & Prob. F(1,74) & 0.0057 \\
\hline & Obs*R-squared & 0.317771 & Prob.Chi Square(1) & 0.0057 \\
\hline \multirow{3}{*}{ Shallot } & F-statistic & 3.097777 & Prob. $F(1,74)$ & 0.0082 \\
\hline & & & Prob.Chi- & \\
\hline & Obs*R-squared & 3.053669 & Square(1) & 0.0080 \\
\hline \multirow[b]{2}{*}{ Garlic } & F-Statistic & 0.391696 & Prob. F $(1,74)$ & 0.0053 \\
\hline & Obs*R-Squared & 0.400165 & $\begin{array}{l}\text { Prob.Chi- } \\
\text { Square(1) }\end{array}$ & 0.0052 \\
\hline \multirow{2}{*}{ Red Chilli } & F-statistic & 0.002484 & Prob. F(1,74) & 0.0096 \\
\hline & Obs*R-squared & 0.002551 & Prob.Chi Square(2) & 0.0095 \\
\hline Cayenne Pepper & F-statistic & 4.449190 & Prob. F(1,74) & 0.0383 \\
\hline
\end{tabular}




\begin{tabular}{llccc} 
& & \multicolumn{3}{c}{ Prob.Chi- } \\
& Obs*R-squared & 4.310286 & Square(1) & 0.0379 \\
\hline \multirow{2}{*}{ Cooking Oil } & F-statistic & 6.566729 & Prob. F(1,74) & 0.0124 \\
& Obs*R-squared & 6.194510 & Prob.Chi Square(2) & 0.0128 \\
\hline \multirow{2}{*}{ Sugar } & F-statistic & 21.84870 & Prob. F(1,74) & 0.0000 \\
& Obs*R-squared & 17.32419 & Prob.Chi Square(2) & 0.0000 \\
\hline
\end{tabular}

Note: **showed that data is significant at $5 \%$

Table 3 shows the value of price volatility. The results reveal that the total coefficients of $\mathrm{ARCH}$ and GARCH form three price volatility groups. First, the explosive volatility, such as garlic and cayenne pepper, indicates that future consumers of these commodities will face more significant uncertainty and risk. Furthermore, these commodities will lead to a volatile price movement in the future, implying a greater experience shock that consumers will face. Second, commodities with high volatility, such as rice, chicken meat, eggs, shallots, and sugar, indicate that these commodities will cause consumers to face a large shock due to the high unpredictability of price movement. Third, low volatility, such as beef, red chilli, and cooking oil, indicates that consumers will encounter less uncertainty and risk in the future, lowering consumer experience shock.

Table 3 ARCH/GARCH Estimation

\begin{tabular}{|c|c|c|c|c|}
\hline & ARCH/GARCH & H(1)GARCH & & \\
\hline \multirow{2}{*}{ Rice } & $\mathrm{C}$ & 529.0495 & \multirow{2}{*}{$\begin{array}{l}\text { GARCH( }(-1)(\beta) \\
(\alpha)+(\beta)=0.703268\end{array}$} & \multirow[t]{2}{*}{0.043480} \\
\hline & $\operatorname{RESID}(-1)^{\wedge} 2(\alpha)$ & 0.659788 & & \\
\hline & \multicolumn{4}{|c|}{ ARCH/GARCH Estimation: ARCH(1)GARCH(1) } \\
\hline \multirow{2}{*}{ Chicken Meat } & $\mathrm{C}$ & 3773.236 & \multirow{2}{*}{$\begin{array}{l}\operatorname{GARCH}(-1)(\beta) \\
(\alpha)+(\beta)=0.982309\end{array}$} & \multirow{2}{*}{1.132208} \\
\hline & $\operatorname{RESID}(-1)^{\wedge} 2(\alpha)$ & -0.149899 & & \\
\hline & \multicolumn{4}{|c|}{ ARCH/GARCH Estimation: ARCH(1)GARCH(1) } \\
\hline \multirow{2}{*}{ Beef } & $\mathrm{C}$ & 872286.8 & GARCH(-1) ( $\beta)$ & \multirow[t]{2}{*}{-0.508692} \\
\hline & $\operatorname{RESID}(-1)^{\wedge} 2(\alpha)$ & -0.080536 & $\alpha_{i}+\beta_{j}=-0.589228$ & \\
\hline \multicolumn{5}{|c|}{ ARCH/GARCH Estimation: ARCH(1)GARCH(1) } \\
\hline \multirow{2}{*}{ Egg } & $\mathrm{C}$ & 8791.605 & $\operatorname{GARCH}(-1)(\beta)$ & 0.635686 \\
\hline & $\operatorname{RESID}(-1)^{\wedge} 2(\alpha)$ & 0.120469 & \multicolumn{2}{|c|}{$(\alpha)+(\beta)=0.756155$} \\
\hline \multicolumn{5}{|c|}{ ARCH/GARCH Estimation: ARCH(1)GARCH(1) } \\
\hline \multirow{2}{*}{ Shallot } & $\mathrm{C}$ & 8052.770 & $\operatorname{GARCH}(-1)(\beta)$ & 1.105841 \\
\hline & $\operatorname{RESID}(-1)^{\wedge} 2(\alpha)$ & -0.147325 & \multicolumn{2}{|c|}{$(\alpha)+(\beta)=0.958516$} \\
\hline \multicolumn{5}{|c|}{ ARCH/GARCH Estimation: ARCH(1)GARCH(1) } \\
\hline \multirow{2}{*}{ Garlic } & $\mathrm{C}$ & -2092.984 & GARCH(-1) ( $\beta)$ & 1.084596 \\
\hline & $\operatorname{RESID}(-1)^{\wedge} 2(\alpha)$ & -0.072458 & $\alpha_{i}+\beta_{j}=1.012138$ & \\
\hline \multicolumn{5}{|c|}{ ARCH/GARCH Estimation: ARCH(1)GARCH(1) } \\
\hline \multirow{2}{*}{ Red Chilli } & $\mathrm{C}$ & 681048.5 & $\operatorname{GARCH}(-1)(\beta)$ & 0.594589 \\
\hline & $\operatorname{RESID}(-1)^{\wedge} 2(\alpha)$ & -0.114103 & \multicolumn{2}{|c|}{$(\alpha)+(\beta)=0.480486$} \\
\hline \multicolumn{5}{|c|}{ ARCH/GARCH Estimation: ARCH(1)GARCH(1) } \\
\hline \multirow{2}{*}{ Cayenne Pepper } & $\mathrm{C}$ & 455495.8 & $\operatorname{GARCH}(-1)(\beta)$ & 0.065322 \\
\hline & $\operatorname{RESID}(-1)^{\wedge} 2(\alpha)$ & 1.116746 & \multicolumn{2}{|c|}{$(\alpha)+(\beta)=1.182068$} \\
\hline \multicolumn{5}{|c|}{ ARCH/GARCH Estimation: ARCH(1)GARCH(1) } \\
\hline \multirow{2}{*}{ Cooking Oil } & $\mathrm{C}$ & 2014.795 & GARCH(-1) $(\beta)$ & 0.188711 \\
\hline & $\operatorname{RESID}(-1)^{\wedge} 2(\alpha)$ & 0.194833 & $\alpha_{i}+\beta_{j}=0.383544$ & \\
\hline \multicolumn{5}{|c|}{ ARCH/GARCH Estimation: ARCH(1)GARCH(1) } \\
\hline \multirow{2}{*}{ Sugar } & $\mathrm{C}$ & -0.224320 & GARCH(-1) ( $\beta)$ & 0.963208 \\
\hline & $\operatorname{RESID}(-1)^{\wedge} 2(\alpha)$ & -0.037209 & $\alpha_{i}+\beta_{j}=0.925999$ & \\
\hline
\end{tabular}

During the COVID-19 pandemic in Indonesia, the government applies several policies, one of them is Large-Scale Community Activities Restriction Policy (PSBB), which caused disruption in the distribution of strategic food commodities and 
decreased demand due to production restrictions and operating hours of restaurants / cafes / hotels / catering. As a result, product sales at the retail level fluctuate(Dermoredjo et al., 2020)(Sadiyah et al., 2021). Food commodity price fluctuations are primarily caused by an imbalance in supply and demand from consumers(Agustian, 2020). Rice, cooking oil, sugar, and chicken eggs are commodities with relatively stable prices because these three foods are normal types of goods, meanwhile these commodities have high volatility. Spice commodities such as shallot, garlic, red pepper, and cayenne pepper have very variable prices. Beef commodities are expected to peak in May 2021 as a result of the presence of Idhul Fitri. Price fluctuations are influenced not only by regional restrictions, but also by other factors(Sadiyah et al., 2021). Uncontrolled supply has a significant impact on rising food prices, increasing the experience shock face by consumers. Climate change, natural disasters, economic crises, and other external shocks, such as the COVID-19 pandemic, can all have an impact on supply constraints. However, the increase in agricultural production is not immediate because it is linked to infrastructure, land area, technology, and expertise, all of which require long-term investment and management(Covid- \& Firdaus, 2021). The COVID-19 pandemic's impact on food price fluctuations has become a major source of concern. FAO (2020) issues a strong warning about each country's mitigation efforts in the face of the impact of COVID-19, which will, of course, disrupt food supply. It is expected that food supply through the global supply chain will have an impact on the situation in several countries, including Indonesia. According to FAO, this impact will be felt between April and May 2020(Covid- \& Firdaus, 2021). Thus, distribution or logistics routes are becoming increasingly critical as some commodities become immensely valuable in the middle of the COVID-19 pandemic(Hirawan \& Verselita, 2020). Therefore, determining the vulnerability indices at the national level is crucial in helping the policymakers and the World Health Organization (WHO) to control better and mitigate the impact of the pandemic more efficiently(Beig et al., 2019).

\section{CONCLUSION}

Price volatility is divided into three groups. First, the tremendous volatility of commodities such as garlic and cayenne pepper shows that future customers will confront higher uncertainty and danger. Furthermore, these goods will cause volatile price movements in the future, meaning that consumers would endure greater experience shock. Second, commodities with significant volatility, such as rice, chicken meat, eggs, shallots, and sugar, imply that these commodities will cause consumers to confront a large shock due to their high price volatility. Third, low volatility, like as meat, red chili, and cooking oil, indicates that consumers will confront less uncertainty in the future. The influence of the COVID-19 epidemic on food price fluctuations has become a serious topic of concern. Food supply through the global supply chain is projected to impact the situation in various nations, including Indonesia. As a result, distribution or logistics routes are becoming increasingly important as some items become extremely valuable during the COVID-19 pandemic.

\section{ACKNOWLEDGEMENTS}

This research was funded by Brawijaya University, through Hibah Peneliti Pemula (HPP) with contract number 536.125.1/UN10.C10/PN/2021

\section{REFERENCES}

Agustian, A. (2020). Strategi Stabilisasi Harga Pangan Pokok Pada Era Pandemi Covid19. Pusat Sosial Ekonomi Dan Kebijakan Pertanian, 3, 389-390.

Anindita, R., Baladina, N., Laili, F., \& Pudjiastuti, A. Q. (2017). Food Demand in Indonesia. International Journal of Applied Business and Economic Research, 15(22), 661671.

Beig, G., Sahu, S. K., Singh, V., Tikle, S., Sobhana, S. B., Gargeva, P., Ramakrishna, K., Rathod, A., \& Murthy, B. S. (2019). The Impact of COVID-19 on Globalization. Science of the Total Environment, 136126.

https://doi.org/10.1016/j.onehlt.2020.100 180

Covid-, S. P., \& Firdaus, M. (2021). Disparitas Harga Pangan Strategis Sebelum dan. 10(2), 107-120.

Dermoredjo, S. K., Saputra, Y. H., \& Azahari, D. H. (2020). Dampak pandemi covid-19 terhadap perdagangan dalam negeri komoditas pertanian. Dampak Pandemi Covid-19: Perspektif Adaptasi Dan Resilensi Ekonomi Pertanian, 15, 127148.

Ezeaku, H. C., Asongu, S. A., \& Nnanna, J. (2021). Volatility of international commodity prices in times of COVID-19: Effects of oil supply and global demand shocks. Extractive Industries and Society, 8(1), 257-270. 
https://doi.org/10.1016/j.exis.2020.12.01 3

Hirawan, F. B., \& Verselita, A. A. (2020). Kebijakan Pangan di Masa Pandemi Covid-19. Csis Commentaries, april(CSIS Commentaries DMRU-048-ID), 1-7.

Marvasti, A., \& Lamberte, A. (2016). Commodity price volatility under regulatory changes and disaster. Journal of Empirical Finance, 38, 355-361. https://doi.org/10.1016/j.jempfin.2016.0 7.008

Piot-Lepetit, I. (2011). Price volatility and Price Leadership in the EU Beef and Pork Meat Market. In Methods to Analyse Agricultural Commodity Price Volatility (pp. 85-105).

Sadiyah, F. N., Pertanian, P., \& Magelang, Y. (2021). Impact of the Covid-19 Pandemic on Economic Growth and Agricultural Commodity Trade-in Indonesia. Jurnal Ekonomi Pertanian Dan Agribisnis (JEPA), 5, 950-961. https://doi.org/10.21776/ub.jepa.2021.00 5.03 .30

Sharif, A., Aloui, C., \& Yarovaya, L. (2020). COVID-19 pandemic, oil prices, stock market, geopolitical risk and policy uncertainty nexus in the US economy: Fresh evidence from the wavelet-based approach. International Review of Financial Analysis, 70(April), 101496. https://doi.org/10.1016/j.irfa.2020.10149 6
Silalahi, D. E., \& Ginting, R. R. (2020). Strategi Kebijakan Fiskal Pemerintah Indonesia Untuk Mengatur Penerimaan dan Pengeluaran Negara Dalam Menghadapi Pandemi Covid-19. Jesya (Jurnal Ekonomi \& Ekonomi Syariah), 3(2), 156167.

https://doi.org/10.36778/jesya.v3i2.193

Uddin, M., Chowdhury, A., Anderson, K., \& Chaudhuri, K. (2021). The effect of COVID - 19 pandemic on global stock market volatility: Can economic strength help to manage the uncertainty? Journal of Business Research, 128(February), 3144.

https://doi.org/10.1016/j.jbusres.2021.01 .061

Yamali, F. R., \& Putri, R. N. (2020). Dampak Pandemi Covid-19 Terhadap Ekonomi Indonesia. Ekonomis: Journal of Economics and Business, 4(2), 384-388. https://doi.org/10.33087/ekonomis.v4i2. 179 